\title{
On the Development Trend of English Teaching in Private Colleges and Universities
}

\author{
Xiong Cailan,Ai Xizhen \\ Nanchang Institute of Science \&Technology, Nanchang 330108, China
}

\begin{abstract}
With the continuous development of private colleges, the development trend of the basic discipline college English has become one of the hot issues of concern. Different from the college English teaching in colleges and universities, the private colleges should find the orientation, actively explore the development trend of college English teaching, constantly explore the teaching new ideas with its own characteristics, keep pace with the times, improve teaching quality and promote comprehensive strength.

Keywords: Private Colleges; College English; Development Trends
\end{abstract}

\section{Introduction}

The practice and reform of college English teaching methods has been attaches great importance of the foreign language world. With the further development of China's economy and the rising of reform and opening up, China and other countries in the world in the field of economy, science and technology, military and cultural exchanges and cooperation presents unprecedented prosperity of the situation, English has become China's foreign propaganda and participation in international exchanges important carrier. How to proceed from the English teaching status and characteristics of our country, comply with the international and domestic development requirements, efforts to cultivate the solid foundation of basic skills, good English listening, speaking, reading and writing talent and translation ability, become our English teaching especially in College English teaching aim. As one of the bases for the cultivation of talents in higher education, private higher education institutions should take on the task of training high-level English talents. Private universities in the English teaching and training practical 
English talents has achieved great development, but we must clearly recognize that there are some problems in English teaching in private colleges. Therefore, the study of the development trend of private college English teaching is in line with the current educational situation and has strong practical guiding significance.

\section{English orientation of private college}

In 2007, The Education Department of our country has set up a normative document :"In view of the teaching resources, students' entrance level and the social needs of the national institutions, in practice, in order to make private colleges training the amount of students practical English ability can meet the needs of the market, private universities must improve their teaching methods to develop teaching content, which should be scientific and reasonable in the country to permit the scope of policy. So the private four-year colleges and universities should adjust the positioning according to the social needs, get rid of exam-oriented and knowledgeable. In practice, private colleges and universities must pay attention to the adaptability of English teaching, pay attention to the cultivation of students' practical ability, so that the students can be adapted to the needs of the market.

\section{Analysis of the present situation of English teaching in private colleges and universities}

The college English teaching curriculum in the private colleges and universities is the same as the general university: do not pay attention to personalized teaching, teaching materials are boring; the process of teaching cannot mobilize the enthusiasm and initiative of students. And the results are not the competitive advantage of private college graduates, the change of market demand estimation, lack of employment direction English; In the teaching mode, mainly dependent on teachers' teaching, In terms of materials and lack of features over a single, and completely derailed the actual needs, cannot play its due role.

In the past few years, in recent years, the promotion of teaching evaluation, a large number of private colleges and universities to introduce younger master, the teachers present a younger trend. One hand, young teachers are superior to older teachers in accepting advanced teaching concepts and using modern teaching methods, and are more willing to communicate with their young teachers. The students in private colleges are especially weak in English application ability. As the main source of private institutions of higher vocational college students, these students in the high school stage is generally weak English foundation, learning interest is not high, self-control is not strong. After the high school learning stage, after stepping on the university campus, as a result of the university study by self-study, self management, students do not like to stay in their parents around, 
subject to discipline and restrictions. The lack of supervision of parents and teachers to learn, unlike in the past work, a lot of people holding mixed diploma mentality for the exam is also very indifferent attitude, the results also hold not only for high clearance psychology. They can't understand even the most basic and simplest spoken English, which undoubtedly brings obstacles to English teaching. One hand, teachers are lack of experience, on the other hand, the students' lack of interest, so the effect of English Teaching in private schools is poor.

The professional setting of private colleges and universities is practical, and it is generally popular in the society the professional. Private colleges and universities due to the lack of capital, audio-visual equipment is aging, backward, frequent failure. The number of multimedia classroom is relatively small, cannot meet all teaching requirements. Some of the data should not be displayed with multimedia display students, students cannot intuitively understand some knowledge, and teachers can only use language to communication, teaching effect greatly reduced. Individual professional can guarantee the multimedia teaching environment, but cannot spread to every major. The private college students have great individual differences and strong sense of reality.

\section{The trend of College English Teaching in Private Colleges}

Private colleges and universities have many unsatisfactory places in their English Teaching, the fundamental reason is that demand from teaching and not fully, one does not do what one has learned and the actual derailment. This not only affects the students' learning motivation and interest, but also greatly reduced their ability to practice English.

The Ministry of education proposed in the requirements to College English Curriculum: since the number of college students in our country is increasing rapidly and the relatively limited teaching resources, we should make full use of multimedia and network technology brings the opportunity to improve the teacher centered teaching mode in the new teaching mode. Along with the rapid development of networking technology, private colleges and universities in the process of changing the mode of English teaching in order to effectively combine the teaching mode and networking technology, private colleges and universities can explore teaching methods to meet the individual learning on the basis of practice, and actively develop the network teaching resources, reform the traditional single teaching model will have a positive effect on College English teaching.

Multimedia Classroom English teaching and learning combined with computer network. Meet the requirements of constructivism theory. The concept of knowledge emphasizes students as the center, and emphasizes the main body of the students in the cognitive process. Help to stimulate students' learning initiative. Only by cultivating a reasonable individualized learning model and the enthusiasm of autonomous learning can achieve the goal of education reform. The computer network based on autonomous learning will effectively promote 
students' autonomous learning ability; set up good English learning environment students for private colleges, enhancing the ability of autonomous learning in College English teaching will have a positive impact.

American psychologist Bloom proposed the "Mastery Learning Theory", he advocated "give students enough time to learn, and enable them to acquire scientific learning methods, through their own hard work, they should be able to master the learning content, need to use different methods to teach different students of different teaching contents to sustain attention. The English level of the private college students is very low, and the students' English level is also very different. Some students' level of English is high, some students' level of English is low, of course, and the difference between student's English levels is also great. Based on this situation, private college English teaching mold should be more suitable for students and school conditions, Private colleges can choose different professional college English textbooks, or the same textbook selection schedule is different; reduce the students from learning more difficult knowledge anxiety, the different levels of students learning English can make progress. To improve the general knowledge, skills and abilities level of all students. Private colleges and universities should establishment of multi-level English teaching courses for different levels of students, so that different levels of students in the learning process can be very satisfied, it will help students improve the efficiency of learning. So as to improve the efficiency of cooperation and communication between teachers and students, optimize the teaching effect.

Private college students' learning habits are not good, in the high school those students are lack of interest in English, poor English foundation of the private colleges and universities, learning enthusiasm has not improved; further reduce the interest in learning English, especially in grammar learning. Teachers in teaching can be appropriate to weaken the grammar of the more complicated department about English culture, strengthen the appreciation of aspects. To make the students understand the East and the West.

The differences in language, culture, ways of thinking and values, and gradually cultivate the ability to understand the language, the ability to imitate, and ultimately rose to the real meaning of language communication skills. Cultural factors influence the development and evolution of language inheritance and change. Any language is not isolated from the culture, learning a language is closely related to the cultural background knowledge of the language. English culture is a window to the world, at the same time, students in the direct perception of language to appreciate the language of the survival of the different social and cultural diversity, to understand the differences between different nationalities broaden their horizons, enhance the cultural taste of students and personal comprehensive quality.

The key task of foreign language teaching is to improve the students' ability of cross-cultural application. Students should be based on high school English learning, improve the learning interest, at the same time to pay attention to their own cultural differences between Chinese and other countries, strengthen their language learning, enhance their sensitivity of language, combine language learning and cultural differences, overcoming the communicative culture in the 
misuses and gradually improve their own energy power. Language and culture learning is a gradual process the renewal, the field of vision continues to open, the thought will be able to be nimble, to the new culture insight will enhance greatly.

It is not only the theoretical grammar but also the ability to learn and cultivate the ability of the students in private colleges and universities. English teaching is the language teaching, language is a kind of social phenomenon, individual language behavior can only be developed in the society and communication. Actively carry out English extracurricular activities, let the students have enough time to accept the language skill training practice, realize the change of student's thinking style transfer of English knowledge and comprehensive ability, awareness and ability to cultivate students' cooperative learning, harmony, and the combination of English teaching and training of students to adapt to the needs of society, organization communication ability, cooperation ability and so on.

According to the Department in charge of education requirements for College English teaching, one hand, and private colleges should pay attention to cultivate students' comprehensive ability, and improve the ability to consciousness using English of students. On the other hand, private colleges should also pay attention to cultivation of students' autonomous learning ability, so that these students can better adapt to the future market competition, can make a better contribution to the country. And play dubbing, role playing activities can improve their listening and speaking skills and to promote the overall ability to improve students' English. At the same time, it can also be used in other ways, such as: English corner, Tourism Association, English lectures, English radio programs, oral English, English movies, English speaking, English knowledge contest, English reading, English party drama, calligraphy competition and other forms of extracurricular activities. So that the students of private colleges and universities are actively involved in the fun of learning English, expand knowledge; effectively consolidate the language knowledge and skills acquired in the classroom.

It is necessary to establish the formative assessment. On the one hand, formative assessment can promote the students' learning enthusiasm, constantly change their way of learning, on the other hand, formative assessment can enable students to obtain the sense of satisfaction, to actively take the initiative to participate in the assessment system, make one become a member of active learning.

American psychologist Bloom proposed: formative assessment is not only an important means to improve the teaching work, improve the learning effect, for the formation of the teaching object of teaching, and promote students' intelligence development, to fully tap the potential of the important means of students' learning.

Formative assessment is particularly suitable for private colleges and universities, is conducive to strengthening the students' self-confidence, because this kind of examination method takes into account the students' learning attitude, stages of learning results, performance and other aspects of the classroom, give students hope that the effort to add appropriate methods will be closer to success. 


\section{Conclusion}

Nowadays, the teaching reform and teaching quality of private universities are increasing day by day. It can continuously explore the new teaching ideas combined with the characteristics of their own development the new method, in order to highlight the practical principle, so as to keep pace with the times.

\section{References:}

[1] Zheng X D. On the Type and Development Trend of the Sports Teaching Mode in Colleges and Universities[J]. Fujian Sports Science \& Technology, 2007.

[2] Zhang J. Status quo and development trend of psychological experimental teaching in colleges and universities[J]. Experimental Technology \& Management, 2013.

[3] Bao J G. Development-oriented Funding for Education_the Development Trend of Funding in Colleges and Universities[J]. Journal of Beijing Institute of Education, 2015.

[4] $\mathrm{Xu} \mathrm{Z}$. Discussion on Developing Trend of Running Physical Education Specialty in General Colleges and Universities[J]. Journal of Beijing University of Physical Education, 2001.

[5] Jie Y U. On the Development Trend of Wushu and Sanda in Colleges and Universities[J]. Journal of Huaihai Institute of Technology, 2012.

[6] Martínez Solano P. Acquisition of financial management skills in the new framework for adaptation to the EHEA. Póster[J]. 2011.

[7] Zhang S, Zhang X. The Analysis of Specialty Set-up in College of Physical Education in 2007 2011 Eastern Region[J]. Contemporary Sports Technology, 2013.

[8] Liu X H, Qin-Lin S U. Thoughts about opening such a course as Ancient Chinese Health Care History for social physical education specialty in institutes of higher learning[J]. Journal of Physical Education, 2007.

[9] Cai Z L, Luo Y D, Kong J F, et al. Current situation of management of the (regular) traditional national physical education specialty in China[J]. Journal of Physical Education, 2007. 